Jurnal Riset Manajemen Sains Indonesia (JRMSI) | Vol 12, No. 2, 2021 e-ISSN: 2301-8313

http://doi.org/10.21009/JRMSI

DOI: doi.org/10.21009/JRMSI.009.1.010

\title{
Pengaruh Status Pegawai dan Job Embeddedness Terhadap Turnover Intention Karyawan Universitas Negeri Jakarta
}

\author{
Dra. Sholikhah, MM. \\ Jurusan Manajemen Fakultas Ekonomi Universitas Negeri Jakarta \\ email: sholikhahlabs@gmail.com \\ DR. Christian Wiradendi Wolor, SE, MM \\ Jurusan Manajemen Fakultas Ekonomi Universitas Negeri Jakarta \\ email : christianwiradendi@unj.ac.id
}

\begin{abstract}
ABSTRAK
Tujuan penelitian ini adalah untuk mengetahui 1). Gambaran tenang status pegawai, job embeddedness dan turnover intention 2) Pengaruh antara startus pegawai terhadap turnover intention dan 3).Pengaruh job embeddedness terhadap turnover intention karyawan Universitas Negeri Jakarta. Populasi pegawai yang berstatus kontrak atau honorer khususnya tenaga non kependidikan dengan teknik pengambilan sampel random sampling dan jumlah renpoden 170. Data yang digunakan adalah data primer diperoleh dari hasil jawaban responden dan diolah dengan SPSS 22. Variabel bebas terdiri dari status pegawai dengan dimensi perjanjian waktu kerja tertentu dan perjanjian kerja waktu tidak tertentu sementara job embeddedness dengan dimensi fit organization, fit community, link organization, link community, sacrifice organization dan sacrifice community sedangkan variabel terikatnya adalah turnover intention dengan dimensi.Hasil analisa deskriptif status pegawai baik karyawan kurang mempermasalahkan statusnya dan job embeddedness baik, kondisi tersebut diindikasikan karena sebagian besar karyawan merasa nyaman dalam lingkungan kerja dan sulitnya peluang kerja, Disisi lain hasil analisa statistik menunjukkan bahwa status pegawai dan job embeddedness secara signikan mempengaruhi turnover intention
\end{abstract}

Kata Kunci : Status pegawai, Job Embeddedness, Turnover Intention 
Jurnal Riset Manajemen Sains Indonesia (JRMSI) | Vol 12, No. 2, 2021 e-ISSN: 2301-8313

\section{Latar Belakang}

Sejalan pertumbuhan dan perkembangan organisasi akan muncul berbagai permasalahan yang berhubungan dengan sumber daya manusia seperti turnover intention karyawan. Abdillah (2012) menyatakan bahwa turnover merupakan pergerakan keluarnya tenaga kerja dari tempatnya bekerja, turnover intention diartikan sebagai niat karyawan untuk keluar dari organisasi baik dilakukan dalam bentuk pengunduran diri maupun pemberhentian. Dan turnover intention dimaknai sebagai suatu keadaan dimana karyawan memiliki niat yang dilakukan secara sadar untuk mencari suatu pekerjaan lain sebagai alternatif di organisasi yang berbeda.

Tingginya turnover intention dapat menggambarkan kurang efektifnya kinerja organisasi karena hilangnya karyawan yang berpengalaman (Andini, 2006) . Universitas Negeri Jakarta bergerak dibidang pendidikan untuk memenuhi kebutuhan karyawan merekrut tenaga kerja pada posisi dosen, staf administrasi sebagai tenaga kontrak. Hal ini dilakukan karena terbatasnya jatah penerimaan pegawai negeri untuk mengganti karyawan memasuki masa purna bakti. Berdasarkan hasil wawancara dengan bagian SDM pegawai tetap non PNS berjumlah 484 dan yang mengundurkan diri atau diberhentikan. Kategori karyawan di Universitas Negeri Jakarta terdiri dari Pegawai Negeri Sipil (PNS), Pegawai tetap atau sering disebut honorer dan tenaga oursourcing.

Pergerakan turnover intention karyawan perlu mendapatkan perhatian pihak manajemen karena ini dapat mencerminkan adanya rendahnya loyalitas karyawan terhadap pelayanan (Evan dan Rahayu, 2015), selain itu ketidakberhasilan perusahaan atau instansi memperhatikan karyawan biasanya ditunjukkan adanya indikasi terjadinya turnover karyawan (Titis et al., 2016), Sebaliknya jika turnover intention rendah perusahaan dapat menghemat biaya sehingga dapat meningkatkan efektivitas dan efisiensi perusahaan.

Banyak faktor penyebab terjadinya tornover intention seperti status pegawai, job embeddedness yang rendah, kepuasan kerja, stres kerja dan lain sebagainya. Krisis ekonomi yang diawali dengan terjadinya krisis moneter menjelang 1998 memaksa pemerintah mengeluarkan kebijakan Pasar Kerja Fleksibel yang dipersyaratkan International Monetary Fund (IMF), World Bank dan organisasi buruh dunia yang lebih beken disebut International Labour Organization (ILO) untuk diberikan bantuan dalam rangka mengatasi kiris ekonomi Indonesia dan munculah pegawai kontrak dan penerapannya semakin meluas dan kondisi ini 
Jurnal Riset Manajemen Sains Indonesia (JRMSI) | Vol 12, No. 2, 2021 e-ISSN: 2301-8313

tentunya menciptakan posisi tenaga kerja lemah dan dirugikan karena adanya ketidakjelasan kelangsungan dalam bekerja disamping itu hak terbatas dan pengembangan karir nyaris tidak berkembang.

Work status atau status kepegawaian didefinisikan sebagai kedudukan atau status hukum seseoang sebagai pekerja ditempat kerja. Status kepegawaian dapat menentukan hak dan kewajiban bagi seorang pekerja sehingga penting seorang individu untuk mengetahui kedudukan dan status hukum dirinya sebagai seorang pekerja. Penggajian atau upah pekerja merupakan salah satu masalah yang dapat timbul karena tidak ketidakjelasan kepegawaian (Jawa Pos 2012). Ini artinya status kepegawaian tidak jelas akan berdampak pada ketidakjelasan hak yang seharusnya mereka dapatkan seperti gaji dan tunjangan yang sesuai serta kenaikan pangkat.

Universitas Nengeri Jakarta yang bergerak dibidang pendidikan tidak dapat menghindar dari kebijakan global dalam memenuhi ketuhan tenaga kerja merekrut tenaga kerja kotrak dan bakhkan bekerja sama dengan perusahaan out sourcing yang menyalurkan tenaga clining service, Hal ini disebabkan kebijakan pemerintah yang membatasi tenaga kerja berstatus ASN karena kondisi keuangan negara dibarengi dengan tidak seimbangnya karyawan memamsuki masa purna bakti dengan jumlah yang terima. Pegawai UNJ terdiri dari ASN, kontrak dan out soursing. Status karyawan kontrak kondisi saat ini tidak memungkinkan dapat mengembangkan karir karena dibatasi peraturan dan hak secara finansialpun lebih lemah dibandingkan dengan posisi ASN. Hasil wawancara tenaga diluar ASN bisa menjadi pegawai abdi sipil negara , sementara tenaga kerja kontrak mengharapkan dapat naik posisi menjadi ASN dengan pertimbangan adanya keamanan dan kenyamanan kerja, jelas secara status, finansial lebih baik dan keberlangsungan kerja lebih terjamin.

Hubungan positif antara karyawan dengan lingkungan kerja dan kelekatannya terhadap organisasi atau perusahaan dikenal dengan sebutan job embeddedness, dan job embeddedness didefinisikan sejauh mana seseorang itu merasa lekat atau terintegrasi dalam lingkungan kerjanya, dan ini merupakan fenomena yang terjadi secara alami dan merupakan salah satu kunci untuk memegang retensi karyawan melalui embedded pada individu (Mitchell, 2004). Mitchell et al (2004) menambahkan bahwa karyawan yang merasakan koneksi dan lekat dalam lingkungan kerja dalam organisasi cenderung akan bertahan. 
Jurnal Riset Manajemen Sains Indonesia (JRMSI) | Vol 12, No. 2, 2021 e-ISSN: 2301-8313

Job embeddedness perlu dibangun dan dikondisikan guna mendorong karyawan bisa menampilkan tingkah laku positif dalam pekerjaannya karena job embeddedness merupakan sebuah konstruk yang dapat memprediksi turnover intention, ini berarti semakin tinggi job embeddedness tinggi maka turnover intention rendah dan sebaliknya. Berdasarkan uraian tersebut maka tema penelitian adalah “ Pengaruh Status Kepegawaian dan Job Embeddedness Terhadap Turnover Intention “

\section{TELAAH PUSTAKA}

Turnover intention menurut Mobley (1986) adalah kecenderungan atau niat karyawan untuk berhenti bekerja dari pekerjaannya secara sukarela atau pindah dari satu tempat kerja ke tempat kerja lain menurut pilihannya sendiri. Turnover intention (keinginan berpindah kerja) merupakan kecenderungan atau intensitas individu untuk meninggalkan organisasi dengan berbagai alasan dan diantaranya keinginan untuk mendapatkan pekerjaan yang lebih baik (Ronald dan Milkha, 2014).. Tet dan Meyer (dalam Rodly, 2012) memberikan definisi turnover intention yaitu niat karyawan untuk meninggalkan organisasi sebagai sadar dan hasrat disengaja dari karyawan untuk meninggalkan organisasi, Hal ini dipertegas Bothma dan Roodt (2012) turnover intention adalah intensi atau niat seseorang untuk meninggalkan atau berhenti dari pekerjaan yang merupakan suatu jenis perilaku penarikan diri terhadap pekerjaan.

Menurut Memont et al (2014), turnover intention adalah keiinginan untuk meninggalkan perusahaan secara aktual. Adapun menurut cha et al (2013) turnover intention adalah kemungkinan bahwa individu berharap untuk meningggalkan organisasi di masa depan, sementara Albattat et al (2013) mendefinisikan sebagai tujuan individu untuk meninggalkan atau tetap dalam organisasi, individu yang ingin meninggalkan organisasi kurang perhatian atas pekerjaannya dan tangggung jawabnya rendah untuk menyelesaikan pekerjaan tersebut. Hal ini berdampak pada organisasi untuk menerima atau merekrut karyawan yang terampil dan kualitas baik untuk mendapatkan keunggulan kompetitif. Sehingga hal inilah menjadi tantangan organisasi untuk membuat karyawan tetap bekerja untuk organanisasi. Kondisi ini manajemen harus memperhatikan dan mengutamakan bagaimana cara organisasi lebih bisa menarik karyawan agar turnover lebih rendah agar memperoleh kinerja yang lebih baik bagi organisasi dan memiliki keunggulan kompetitif (Kulaichai Amaraphibal, 2017) 
Jurnal Riset Manajemen Sains Indonesia (JRMSI) | Vol 12, No. 2, 2021 e-ISSN: 2301-8313

Dari beberapa pengertian diatas dapat disimpulkan bahwa tornover intention adalah keinginan pegawai untuk keluar dari perusahaan atau organisasi tetapi belum secara riil dilakukan dan pada giliranya mengacu pada hasil evaluasi individu mengenai kelanjutan hubungan dengan organisasi diwujudkan dalam tindakan pasti meninggalkan organisasi.

Robbins (2006) menjelaskan penarikan diri karyawan keluar dari organisasi (turnover) bisa dibedakan : a). Voluntary turnover (Keluar sukarela) merupakan keputusan karyawan meningggalkan organisasi secara sukarela yang disebabkan seberapa menarik pekerjaan saat ini dan adanya kesempatan pekerjaan yang lebih baik. Model keluar ini ada yang bersifat dapat dihindari ( Avoidable turnover) dengan memberikan gaji atau fasilitas yang lebih baik ataupun tidak bisa dihindari (Unavoidable turnover) dengan alasan pindah kerja, harus tinggal dirumah menunggu anak, mengikuti pasangan dan lain-lain. B). Involuntary turnover ( Keluar tidak sukarela), kondisi ini sebaliknya keluarnya karyawan dari organisasi karena adanya pemecatan. Hal ini menunjukkan pemberi kerja menghentikan secara sepihak atau menghentikan hbungan kerja dengan karyawan dan biasanya keadaan ini tidak bisa dikotrol oleh karyawan yang mengalaminya.

Ada cara penarikan diri dari organiasasi (organizational withdrawl) yang menunjukkan model renca pengunduran diri secara tetap atau bersifat sementara, yaitu : a). Work withdrawl atau penarikan diri dari pekerjaan dengan cara mengurangi durasi waktu kerja bersifat sementara. (Mueller 2003) mengatakan karyawan yang merasa tidak puas dalam pekerjaannya akan melakukan beberapa kombinasi perilaku seperti tidak menghafiri rapat, tidak masuk kerja, menunjukkan kinerja yang rendah dan mengurangi keterlibatannya secara psikologis dari pekerjaan. b). Search for alternatives atau mencari alternatif pekerjaan, perilaku ini biasanya karyawan akan meninggalkan pekerjaannya secara permanen. Hal ini dicerminkan dengan proses pencarian kerja kerja baru sebagai variabel antara pemikiran untuk berhenti bekerja atau keputusan aktual untuk meninggalkan pekerjaan (Muller, 2003).

\section{Aspek Turnover Intention}

Intensi turnover dijelaskan dalam beberapa aspek. Ajzen (Susanti, 2008) dengan teori Theory of Planned Behavior menyatakan ada tiga determinan, yaitu : a). Attitude toward to intention turnover, seberapa jauh individu melakukan evaluasi maupun penilaian mengenai perilaku untuk melakukan turnover. b). Subyective Norm, persepsi individu terhadap tekanan dari lingkungan sosial untuk melakukan atau tidak melakukan turnover. c). Perceived 
Jurnal Riset Manajemen Sains Indonesia (JRMSI) | Vol 12, No. 2, 2021 e-ISSN: 2301-8313

behavioral control, menunjukkkan seberapa jauh tindakan yang diangggap sebagai cerminan pengalaman disamping halangan atau hambatan untuk melakukan turnover sebagai refleksi dari pengalaman masa lampau yang memberikan antisipasi terhadap hal baru

Sedangkan menurut Mobley (1986) menyatakan bahwa turnover intention mengandung tiga (3) aspek yaitu : a). Thinking of Quittng (pikiran untuk keluar organisasi), artinya karyawan memiliki pemikiran untuk mengundurkan diri atau keluar dari perusahaan karena hasil membandingkan antara apa yang diperoleh pada perusahaan saat ini bekerja dengan bekerja pada perusahaan lain. b). Intention to Search ( intensi mencari pekerjaan lain), karyawan berusaha mencari alternatif pekerjaan baik melalui media cetak maupun media elektronik bahkan mengajukan lamaran secara langsung ke perusahaan yang dituju. c). Intention to Quit ( intensi untuk keluar dari organisasi), karyawan mulai menunjukkan sikap dan perilaku keinginannya untuk keluar dari perusahaan.

Work status atau status kepegawaian didefinisikan sebagai kedudukan atau status hukum seseoang sebagai pekerja ditempat kerja. Status kepegawaian dapat menentukan hak dan kewajiban bagi seorang pekerja sehingga penting seorang individu untuk mengetahui kedudukan dan status hukum dirinya sebagai seorang pekerja. Penggajian atau upah pekerja merupakan salah satu masalah yang dapat timbul karena tidak ketidakjelasan kepegawaian (Jawa Pos 2012). Ini artinya status kepegawaian yang tidak jelas akan berdampak pada ketidakjelasan hak yang seharusnya mereka dapatkan seperti gaji dan tunjangan yang sesuai serta kenaikan pangkat. Seseorang yang bekerja pada suatu perusahaanatau organisasi kan terjadi hubungan kerja yang diwujudkan dengan adanya perjanjian kerja antara tenaga kerja dengan pemberi kerja.

Menurut UU ketenagakerjaan ada dua (2) macam status karyawan yaitu :

1. Karyawan tetap yang diikat oleh perjanjian yang dikensl dengan Perjanjian Kerja Waktu Tidak Tertentu (PKWTT) untuk waktu tidak tertentu dengan memungknkan mensyaratkan perjanjian tertentu seperti ada masa percobaan. Sedangkan berdasarkan peraturan Dirjen pajak nomor 31/PJ/2009, menjelaskan pegawai tetap adalah pegawai yang menerima atau memperoleh penghasilan dalam jumlah tertentu secara teratur, termaksud anggota dewan komisaris dan anggota dewan pengawas yang secara terus menerus ikut mengelola perusahaan secara langsung serrta pegawai yang bekerja berdasarkan kontrak untuk jangka 
Jurnal Riset Manajemen Sains Indonesia (JRMSI) | Vol 12, No. 2, 2021 e-ISSN: 2301-8313

waktu sepanjang pegawai yang bersangkutan bekerja penuh (full time) dalam pekerjaan tersebut

2. Karyawan kontrak yang diikat dengan oleh perjanjian kerja untuk waktu tertentu. Dijelaskan dalam UU ketenagakerjaan karyawan kontrak adalah karyawan yang bekerja pada suatu instansi dengan kerja waktu tertentu yang didasari atas suatu kontrak yang disebut dengan Perjanjian Kerja Waktu Tertentu (PKWT).

Karyawan Outsourcing adalah karyawan yang bekerja pada perusahaan tetapi yang bersangkutan tidak ada ikatan secara legal dimana karyawan ditempatkan dan ikatan yang dimimiki hanya terhadap perusahaan dimana karyawan tersebut melamar. Menyangkut keberadaanya diatur dalam UU 13/2003 dan Kemenakertrans 220/MEN/X/2004 tentang syarat-syarat penyerahan sebagian pelaksanaan pekerjaan kepada perusahaan lain. Karyawan outsourcing bisa merupakan karyawan tetap ataupun kontrak, hal ini bergantung kepada sifat pekerjaan ( memenuhi syarat untuk kontrak) dan juga tergantung kebijakan perusahaan outsourcing tersebut.

\section{Job Embeddednes}

Job embeddedness berarti keterikatan karyawan dalam suatu organisasi melalui jaringan sosial yaitu kepercayaan dan kohesi. Embeddedness adalah semua faktor yang melibatkan karyawan dalam pekerjaanya, hal ini bisa terjadi bila terdapat kesesuaian antara nilai pekerjaan dengan nilai individu dan nilai masyarakat dengan nilai individu. Istilah embeddedness digunakan dalam sosialogis untuk menjelaskan proses hubungan sosial pengaruh dan tindakan terhadap kendala ekonomi. Job embeddedness adalah suatu totalitas karyawan yang dipengaruhi secara psikologis, sosial maupun finansial yang berasal dari organisasi dan komonitas yang mempengaruhi pilihan indivividu untuk menetap atau meninggalkan pekerjaannya (Mitchell \& Lee, 2001). Sedangkan menurut (Zhang, Fread, \& Griffeth, 2012) job embeddedness mendefinisikan sebagai suatu konstelasi luas pengaruh psikologis, sosial dan finansial pada retensi karyawan.

Berdasarkan beberapa definisi diatas dapat disentesasikan bahwa job embeddedness merupakan salah satu jaringan yang mampu mendorong karyawan atau individu untuk tetap bertahan dalam organisasi, hal ini diperkuat Zho dan Liu (2010) menyatakan current job embeddedness theory adalah model yang bisa memprediksi perilaku turnover intention karyawan. Aspek Job embeddedness adalah hubungan individu karyawan dengan orang lain 
Jurnal Riset Manajemen Sains Indonesia (JRMSI) | Vol 12, No. 2, 2021 e-ISSN: 2301-8313

atau masyarakat, kesesuaian antara organisasi dan lingkungan dan pengorbanan atau hal yang akan diberikan karyawan ketika meninggalkan organisasi. Ada tiga (3) aspek job embeddedness yaitu :

\section{A. Fit}

Fit didefinisikan sebagai kenyamanan yang dirasakan karyawan terhadap organisasi dan komonitas ( Mitchell, 2011). Berdasarkan teori tersebut nilai pribadi, aspirasi, karir, pengetahuan, ketrampilan dan kemampuan karyawan harus sesuai dengan budaya organisasi, dan dengan persyaratan pekerjaannya secara khusus (Mitchell, 2011). Disamping itu seseorang akan mempertimbangkan kesesuaiannya dengan komonitas dan lingkungannya seperti iklim, kondisi cuaca, budaya umum yang berlaku, keyakinan agama dan kegiatan hiburan. Semakin besar kesesuaian yang dirasakan maka semakin terikat dengan organisasi dalam hal profesional dan personal.

\section{B. Link}

Link diartikan sebagai koneksi formal dan informal antara seseorang, lembaga atau orang lain (Mitchell, 2011). Link dalam organisasi seperti rekan kerja atau tim kerja karyawan, sedangkan link dalam komonitas seperti sanak keluarga, teman-teman dan kelompok social

\section{Sacrifice}

Scrafice diartikan sebagai kerugian yang dirasakan karyawan seperti kehilangan materi atau manfaat psikologis saat meninggalkan suatu pekerjaan (Mitchell, 2011). Karyawan yang meninggalkan organisasi memungkinkan mengalami kerugian yang berhubungan dengan pekerjaan seperti kehilangan rekan kerja yang akrab, kehilangan proyek yang menarik, atau manfaat lain yang diinginkan. Selain kerugian dalam pekerjaan, karyawan akan mengalami kerugian yang berhubungan dengan komonitas seperti kehilangan sebuah perjalanan yang mudah atau keanggotaan club lokal (Zhang, Fried \& Griffeth, 2012)

Sedangkan menurut Thomas dan Daniel (2015) aspek job embeddedness ada enam (6) yaitu

a. Fit-organization, artinya adanya kesesuaian antara karyawan dengan organisasi seperti nilai-nilai individu, karir yang ingin ditekuni dan rencana masa depan sejalan dengan budaya organisasi yang dikembangkan dan tuntutan kerja saat ini baik menyangkut pengetahuan, ketrampilan maupun kemampuan yang dimiliki karyawan 
Jurnal Riset Manajemen Sains Indonesia (JRMSI) | Vol 12, No. 2, 2021 e-ISSN: 2301-8313

b. Fit community, adanya persepsi karyawan yang merasa cocok dengan lingkungan sekitarnya seperti cuaca, budaya setempat, hubungan sosial dan lain sebagainya

c. Link Organization, menunjukkan hubungan secara formal maupun informal antar karyawan, individu dengan kelompok dalam organisasi yang dapat mempengaruhi individu untuk bertahan atau meninggalkan organisasi

d. Link community, mencerminkan hubungan antara individu dengan kelompik lain dalam suatu komunitas, keluarga dan lembaga sosial lain terhadap individu dan memecahkan masalah dan dalam mengambil keputusan dalam rangka mencari solusi atas masalah yang dihadapi

e. Sacrifice organizatin, hal menyangkut persepsi atas biaya materiil maupun psikologis ditanggung karyawan yang meninggalkan pekerjaan dari organisasi tempat bekerja termasuk kehilangan teman baik, kehilangan proyek serta kehilangan tunjangan

f. Sacrifice community, hal ini berkaitan dengan individu yang harus berpindah atau terjadi relokasi. Ini berarti individu meninggalkan komonitas yang menyenangkan/menarik, aman, nyaman dan segala sesuatu yang disenangi dan dihargai adalah hal yang sulit dilakukan individu.

Berdasarkan kerangka tersebut, hipotesa dalam penelitin sebagai berikut :

H1 : Ada pengaruh antara status pegawai terhadap turnover intention

Ho : Tidak ada pengaruh antara status pegawai terhadap turnover intention

$\mathrm{H} 2$ : Ada pengaruh antara job embeddedness terhadap turnover intention

Ho : Tidak ada pengaruh antara job embeddedness terhadap turnover intention

H3: Ada pengaruh antara status pegawai dan job embeddedness terhadap turnover intention

Ho : Tidak ada pengaruh antara status pegawai dan job embeddedness terhadap turnover intention

\section{METOLOGI PENELITIAN}

Metode yang digunakan dalam penelitian ini adalah pendekatan kuantitatif deskriptif dan explanatory, serta teknik penelitian yang digunakan adalah teknik analisis jalur (path analysis) untuk mengetahui hubungan sebab akibat. Data yang digunakan dalam penelitian ini adalah data primer yang didapatkan melalui kuesioner serta wawancara diolah dan 
Jurnal Riset Manajemen Sains Indonesia (JRMSI) | Vol 12, No. 2, 2021 e-ISSN: 2301-8313

dilakukan analisa statistik deskriptif untuk melihat gambaran tentang karakteristik karyawan diberbagai unit. Selanjutnya untuk dapat diketahui status pegawai dan job embeddedness dan pengaruhnya terhadap turnover intentin. Sedangkan teknik pengambilan sampel dilakukan secara random sebanyak 170 responden, pengumpulan data menggunakan instrument penelitian, analisis data bersifat kuantitatif statistik dengan tujuan untuk menguji hipotesis yang telah ditetapkan (Sugiyono, 2010:13). Analisis data menggunakan program SPSS Vs 24 dan dalam penelitian menggunakan metode analisis regresi linier berganda, hal ini untuk menunjukkan hubungan antara variabel satu dengan variabel lainya. Regresi dilakukan untuk mengetahui besarnya pengaruh perubahan dari satu variabel independen terhadap variabel dependen (Gurajati, 1997). Selain itu dilakukan analisa deskriptif untuk mengetahui gambaran setiap variabel dalam penelitian.

Hasil Penelitian

\section{Profil Responden}

Karyawan honorer Universitas Negeri Jakarta sebagian besar laki-laki 95 (55,9\%) dan wanita sebanyak 75 orang $(44,1 \%)$ dengan tingkat pendidikan paling banyak S1 74 orang $(43,5 \%)$ disusul pendidikan terakhir SMA sejumlah 64 orang $(37,6 \%)$ dengan masa kerja sebagian besar antara 5 s/d 10 tahun. Hal ini menunjukkan karyawan tersebut memiliki keterikatan yang kuat dengan lembaga tempat bekerja dengan kualitas yang cukup memadahi dengan dilihar dari latar belakang pendidikan.

Uji instrumen

Uji Validitas dan Reabilitas

Kriteria pengujian validitas yaitu jika rhitung > rtabel (0,361), maka instrumen/ itemitem pernyataan dinyatakan valid. Sebaliknya jika rhitung $<$ rtabel $(0,361)$, dan hasil perhitungan menunjukkan nilai r-hitung > 0,36 sehingga dinyatakan valid.

Tabel 45.

Hasil Uji Validitas

\begin{tabular}{lccc}
\hline \multicolumn{1}{c}{ Variabel } & Pernyataan & Item Valid & Item Tidak Valid \\
\hline Status pegawai & 6 & 6 & 0 \\
Job Embeddedness & 18 & 18 & 0 \\
Turnover Intention & 9 & 9 & 0 \\
\hline
\end{tabular}

Sumber : Data diolah oleh peneliti (2020)

Tabel 4.6

Hasil Uji Reliabilitas 


\begin{tabular}{lccc}
\hline \multicolumn{1}{c}{ Variabel } & $\begin{array}{c}\text { Cronbach's } \\
\text { Alpha }\end{array}$ & Kriteria & Keterangan \\
\hline Status Pegawai & 0,738 & 0,600 & Reliabel \\
Job Embeddedness & 0,864 & 0,600 & Reliabel \\
Turnover Intention & 0,892 & 0,600 & Reliabel \\
\hline
\end{tabular}

Sumber : data diolah Peneliti (2020)

Hasil analisa deskriptif

Karyawan merasa nyaman bekerja di lingkungan Universitas Negeri Jakarta tanpa mempermasalahkan status kepegawaian baik statusnya sebagai karyawan kontrak Perjanjian Kerja Waktu Tidak Tertentu (PKWTT) ataupun yang berstatus Perjanjian Kerja Waktu Tertentu (PKWT) sebesar 88\% dan 18\% yang mempermasalahkan. Jika dikonfirmasikan hasil wawancara dengan para karyawan kondisi tersebut disebabkan karena sulitnya peluang kerja yang tersedia untuk beralih profesi.

Job embeddedness atau keterikatan karyawan secara psikologis, sosial maupun finansial terhadap pekerjaan baik hal ini karena karyawan merasa nilai yang ada pada organisasi dan komonitas sesuai dengan nilai individu sehingga mempengaruhi pilihan indivividu untuk menetap, hal ini didukung Fit-organization 68,2\%, Fit-community sebesar $65,1 \%$, Link-community sebesar 63\% dan Sacrifice-community sebesar 60,52\%.

Turnover intention rendah yang didikung Thinking of Quittng sebesar 14\% artiya sebagaian besar (86\%) karyawan tidak berminat untuk keluar organisasi karena membandingkan dengan apa yang akan diperoleh bila berpindah kerja..Dan Intention to Search sebesar $20 \%$ maksudnya karyawan yang mencari pekerjaan lain dengan mencari lowongan kerja baik melalui media cetak ataupun elektronik sementara 64,81\% tetap memilih tetap bekerja, 


\section{Uji Normalitas}

Tabel 4.10

One-Sample Kolmogorov-Smirnov Test

\begin{tabular}{|c|c|c|}
\hline & & $\begin{array}{l}\text { Unstandardized } \\
\text { Residual }\end{array}$ \\
\hline $\mathrm{N}$ & & 170 \\
\hline \multirow[t]{2}{*}{ Normal Parameters ${ }^{\mathrm{a}, \mathrm{b}}$} & Mean &, 0000000 \\
\hline & Std. Deviation & 9,17001457 \\
\hline \multirow[t]{3}{*}{ Most Extreme Differences } & Absolute &, 047 \\
\hline & Positive &, 047 \\
\hline & Negative &,- 042 \\
\hline \multicolumn{2}{|l|}{ Test Statistic } &, 047 \\
\hline \multicolumn{2}{|l|}{ Asymp. Sig. (2-tailed) } &, $200^{\mathrm{c}, \mathrm{c}}$ \\
\hline \multicolumn{3}{|c|}{ a. Test distribution is Normal. } \\
\hline \multicolumn{3}{|l|}{ b. Calculated from data. } \\
\hline \multicolumn{3}{|c|}{ c. Lilliefors Significance Correction. } \\
\hline d. This is a lower bound of & significance. & \\
\hline
\end{tabular}

Pada tabel 4.10. menunjukkan semua hasil variabel menunjukkan hasil dari Asymp Sig (2-tailed) atau signifikansi sebesar 0,200. Mengacu pada hasil perhitungan maka signifikansi tersebut lebih besar dari 0.05 maka dapat disimpulkan bahwa data berdistribusi normal dan memenuhi syarat melakukan metode analisis regresi linear berganda.

\section{Uji Linearitas}

Tabel 4.11

Hasil Uji Linearitas Variabel Status Pegawai dengan Variabel Turnover Intention

\begin{tabular}{|c|c|c|c|c|c|c|c|}
\hline \multicolumn{8}{|c|}{ ANOVA Table } \\
\hline & & & $\begin{array}{l}\text { Sum of } \\
\text { Squares }\end{array}$ & $\mathrm{df}$ & $\begin{array}{c}\text { Mean } \\
\text { Square }\end{array}$ & $\mathrm{F}$ & Sig. \\
\hline \multirow{5}{*}{$\begin{array}{l}\text { Turnover Intention * } \\
\text { Status Pegawai }\end{array}$} & Between & (Combined) & 15901,668 & 15 & 1060,111 & 11,191 &, 000 \\
\hline & Groups & Linearity & 12346,672 & 1 & 12346,672 & 130,332 &, 000 \\
\hline & & $\begin{array}{l}\text { Deviation from } \\
\text { Linearity }\end{array}$ & 3554,996 & 14 & 253,928 & 1,304 & , 102 \\
\hline & Within Groups & & 14588,808 & 154 & 194,733 & & \\
\hline & Total & & 30490,476 & 169 & & & \\
\hline
\end{tabular}


Jurnal Riset Manajemen Sains Indonesia (JRMSI) | Vol 12, No. 2, 2021 e-ISSN: 2301-8313

Berdasarkan hasil uji linearitas antara variabel status pegawai dengan turnover intention pada Tabel 4.11, diketahui bahwa signifikansi linearity sebesar 0,000. Nilai signifikansi tersebut kurang dari 0,05 sehingga dapat disimpulkan bahwa antara kedua variabel tersebut terdapat hubungan yang linear.

Tebel 4.12

Hasil Uji Linearitas Variabel Job Embeddedness dengan Variabel Turnover Intention

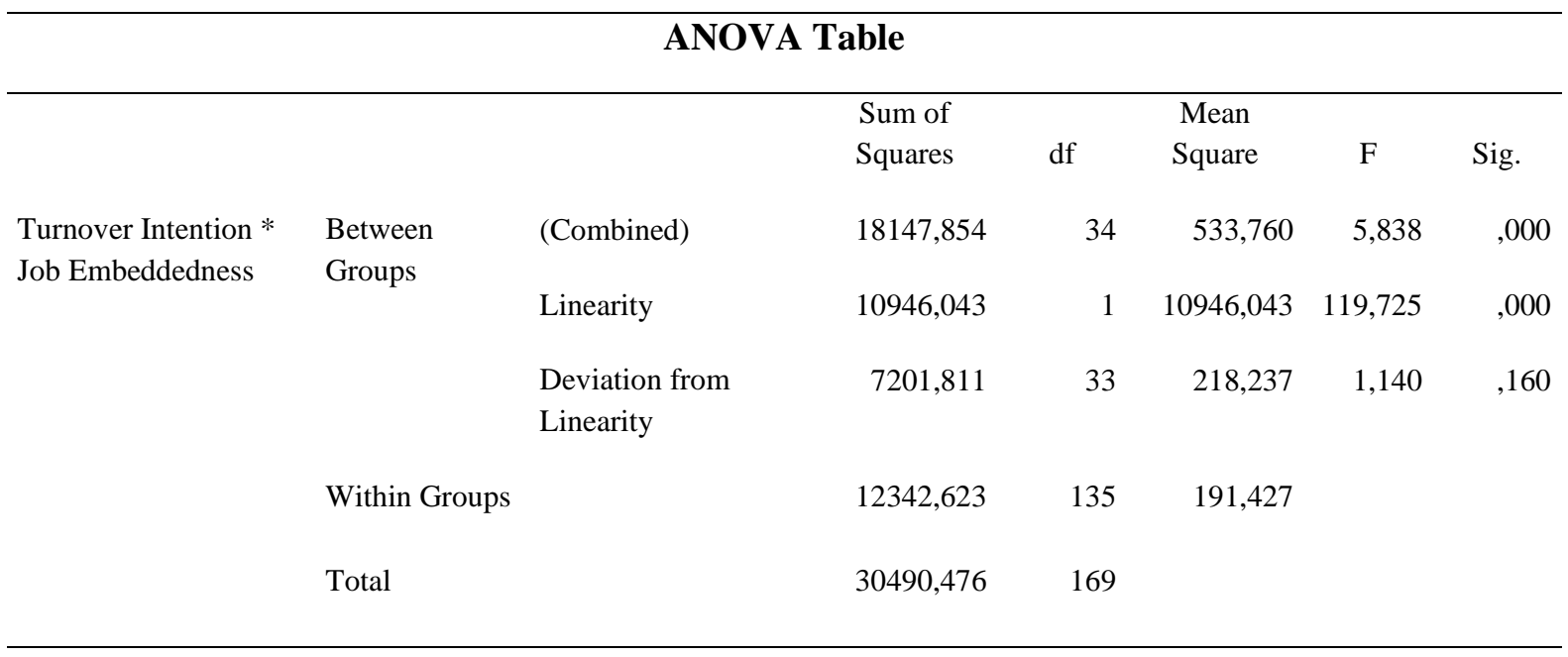

Berdasarkan hasil uji linearitas antara variabel job embeddedness dengan Turnover Intention pada Tabel 4.12, diketahui bahwa signifikansi linearity sebesar 0,000. Nilai signifikansi tersebut kurang dari 0,05 sehingga dapat disimpulkan bahwa antara kedua variabel tersebut terdapat hubungan yang linear.

\section{Uji Multikolinearitas}

Tabel 4. 1

Hasil Uji Multikolinearitas

\begin{tabular}{|c|c|c|c|c|c|c|c|c|}
\hline \multicolumn{9}{|c|}{ Coefficients $^{\mathrm{a}}$} \\
\hline \multirow{2}{*}{\multicolumn{2}{|c|}{ Model }} & \multicolumn{2}{|c|}{$\begin{array}{c}\text { Unstandardized } \\
\text { Coefficients }\end{array}$} & \multicolumn{2}{|l|}{$\begin{array}{l}\text { Standardized } \\
\text { Coefficients }\end{array}$} & \multirow[b]{2}{*}{ Sig. } & \multicolumn{2}{|c|}{ Collinearity Statistics } \\
\hline & & $\mathrm{B}$ & Std. Error & Beta & $\mathrm{t}$ & & Tolerance & VIF \\
\hline 1 & (Constant) & 109,651 & 5,380 & & 20,382 & 000 & & \\
\hline & Status Pegawai & $-1,945$ & ,246 &,- 464 & $-7,917$ & 000 & 813 & 1,230 \\
\hline
\end{tabular}


Jurnal Riset Manajemen Sains Indonesia (JRMSI) | Vol 12, No. 2, 2021 e-ISSN: 2301-8313

$\begin{array}{llllllll}\text { Job Embeddedness } & -, 623 & , 092 & -, 398 & -6,798 & , 000 & , 813 & 1,230\end{array}$

a. Dependent Variable: Turnover Intention

Dilihat dari Tabel 4.13, diketahui angka VIF untuk variabel status pegawai adalah sebesar 1,230 dan angka VIF variabel job embeddedness sebesar 1,230. Nilai VIF kedua variabel kurang dari 5, maka dapat disimpulkan bahwa diantara variabel bebas tersebut tidak ditemukan adanya masalah multikolinearitas. Dengan demikian model regresi dapat diterima

\section{Uji Heteroskedastistitas}

Tabel 4. 2

Hasil Uji Heteroskedastistitas

\begin{tabular}{|c|c|c|c|c|c|}
\hline \multicolumn{6}{|c|}{ Correlations } \\
\hline & & & $\begin{array}{l}\text { Unstandardized } \\
\text { Residual }\end{array}$ & Status Pegawai & $\begin{array}{c}\text { Job } \\
\text { Embeddedness }\end{array}$ \\
\hline \multirow[t]{9}{*}{ Spearman's rho } & Unstandardized Residual & Correlation Coefficient & 1,000 &,- 070 &,- 059 \\
\hline & & Sig. (2-tailed) & 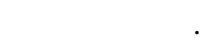 & ,361 & , 448 \\
\hline & & $\mathrm{N}$ & 170 & 170 & 170 \\
\hline & Status Pegawai & Correlation Coefficient &,- 070 & 1,000 &, $473^{* *}$ \\
\hline & & Sig. (2-tailed) & 361 & & 000 \\
\hline & & $\mathrm{N}$ & 170 & 170 & 170 \\
\hline & Job Embeddedness & Correlation Coefficient &,- 059 &, $473^{* *}$ & 1,000 \\
\hline & & Sig. (2-tailed) & ,448 & 000 & \\
\hline & & $\mathrm{N}$ & 170 & 170 & 170 \\
\hline
\end{tabular}

**. Correlation is significant at the 0.01 level (2-tailed).

Dari Tabel 4.14, diketahui korelasi antara organisasi pembelajaran dengan unstandardized residual menghasilkan nilai signifikansi 0,361 dan korelasi antara resiliensi karyawan dengan unstandardized residual menghasilkan nilai signifikansi 0,448. Karena nilai signifikansi lebih besar dari 0,05, maka dapat disimpulkan bahwa pada model regresi tidak ditemukan adanya masalah heterokedastisitas.

\section{Hasil Analisis Regresi}

Hasil Uji F

Hipotesis 3 (H3) : 
Jurnal Riset Manajemen Sains Indonesia (JRMSI) | Vol 12, No. 2, 2021 e-ISSN: 2301-8313

$\mathrm{H}_{\mathrm{o}} \quad$ : Model penelitian status pegawai dan job embeddedness tidak dapat memprediksikan

Tabel 4. 3

ANOVA $^{\mathrm{a}}$

\begin{tabular}{|c|c|c|c|c|c|c|}
\hline Model & & Sum of Squares & df & Mean Square & $\mathrm{F}$ & Sig. \\
\hline \multirow[t]{3}{*}{1} & Regression & 16279,407 & 2 & 8139,704 & 95,653 &, $000^{\mathrm{b}}$ \\
\hline & Residual & 14211,069 & 167 & 85,096 & & \\
\hline & Total & 30490,476 & 169 & & & \\
\hline
\end{tabular}

a. Dependent Variable: Turnover Intention

b. Predictors: (Constant), Job Embeddedness, Status Pegawai

Pada Tabel 4.16, Fhitung yang diperoleh sebesar 95,653. Nilai Fhitung kemudian dibandingkan dengan nilai Ftabel, yang dicari dengan tingkat keyakinan 95\%, dengan df 1 (jumlah variabel-1) atau 3-1 = 2, dan df 2 (n-k-1) atau 170-21=167. Berdasarkan perhitungan tersebut, didapat Ftabel sebesar 3,90 dengan demikian maka Fhitung > Ftabel yaitu 95,653 > 3,90.

Signifikasi pada uji kelayakan model sebesar 0,000, dengan demikian $0,000<0.05$. Dapat disimpulkan bahwa model status pegawai dan job embeddedness dapat memprediksikan variabel turnover intention karyawan UNJ. 
Jurnal Riset Manajemen Sains Indonesia (JRMSI) | Vol 12, No. 2, 2021 e-ISSN: 2301-8313

$\mathrm{H}_{\mathrm{a}} \quad$ : Model penelitian status pegawai dan job embeddednes dapat memprediksikan variabel turnover intention karyawan UNJ

\section{Hasil Uji t}

Untuk melihat persamaan regresi antara status pegawai dan job embeddedness terhadap turnover intention dapat dilihat pada tabel berikut:

Tabel 4.15

Hasil Uji t

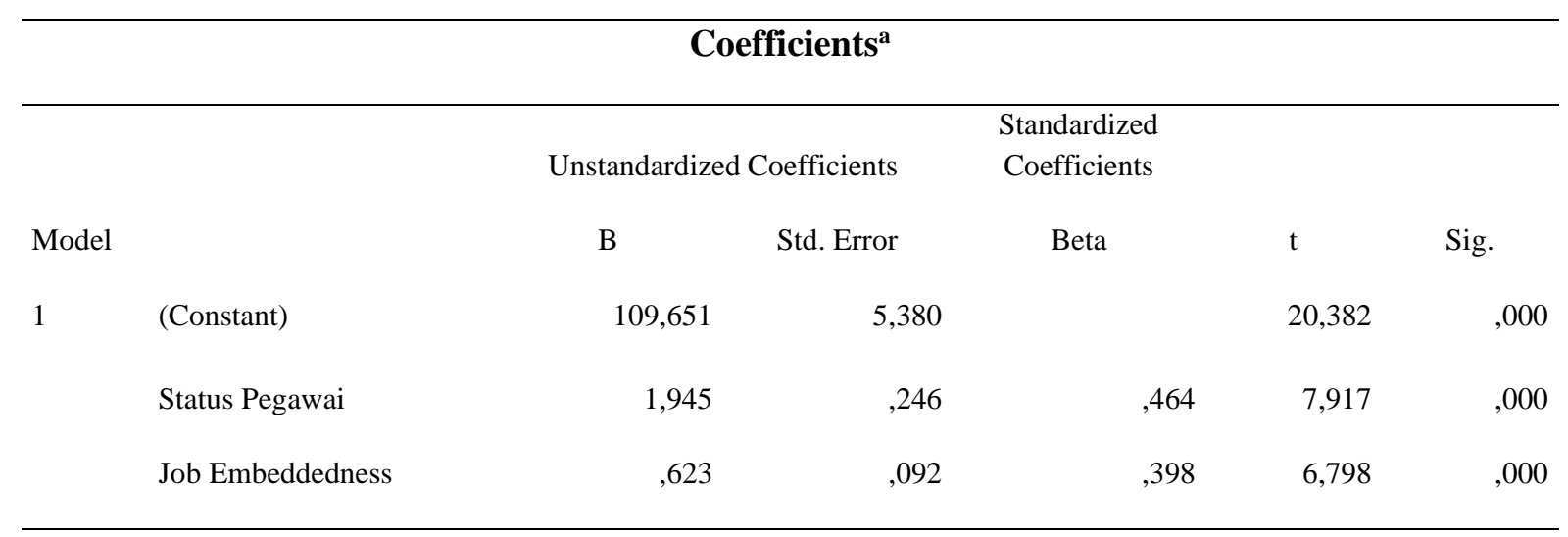

a. Dependent Variable: Turnover Intention

Adapun rumusan hipotesis dan kriteria pengambilan keputusannya adalah:

\section{Rumusan Hipotesis $1\left(\mathrm{H}_{1}\right)$}

$\mathrm{H}_{\mathrm{o}} \quad$ : Status pegawai tidak berpengaruh terhadap turnover intention karyawan UNJ

$\mathrm{H}_{\mathrm{a}} \quad$ : Status pegawai berpengaruh terhadap turnover intention karyawan UNJ

\section{Rumusan Hipotesis $2\left(\mathbf{H}_{2}\right)$}

$\mathrm{H}_{\mathrm{o}} \quad$ : Job embeddedness tidak berpengaruh terhadap turnover intention karyawan UNJ.

$\mathrm{H}_{\mathrm{a}} \quad$ : Job embeddedness berpengaruh terhadap turnover intention karyawan UNJ

Berdasarkan Tabel 4.15 diatas, dapat dilihat bahwa variabel status pegawai memiliki nilai thitung sebesar 7,917. Nilai thitung kemudian dibandingkan dengan nilai t-tabel yang dicari pada $\alpha=5 \%: 2=2,5 \%$ (uji 2 sisi) dengan derajat kebebasan (df) n-k-1 atau 170-2$1=167$, dimana $\mathrm{n}$ adalah jumlah sampel dan $\mathrm{k}$ adalah jumlah variabel bebas. Berdasarkan perhitungan tersebut, didapat t-tabel sebesar 1,972 dengan demikian t-hitung > t-tabel yaitu $7,917>1,972$ serta nilai signifikansi pada variabel status pegawai sebesar 0.000 , dengan demikian 0,000 < 0,05. Dapat disimpulkan bahwa H0 ditolak dan Ha diterima. Artinya status pegawai memiliki pengaruh positif dan signifikan terhadap turnover intention. 
Jurnal Riset Manajemen Sains Indonesia (JRMSI) | Vol 12, No. 2, 2021 e-ISSN: 2301-8313

Pada Tabel 4.15 juga menunjukkan nilai thitung untuk variabel job embeddedness sebesar 6,798, serta nilai signifikansi sebesar 0,000. Hal tersebut menunjukkan bahwa thitung $>$ ttabel yaitu 6,798 > 1,972 dan nilai signifikansi 0,000 < 0,05. Artinya, H0 ditolak dan Ha diterima. Artinya, terdapat pengaruh positif dan signifikan antara job embeddedness terhadap turnover intention.

\section{Hasil Uji Regresi Linear Berganda}

Berdasarkan Tabel 4.15, dapat diperoleh persamaan linear berganda seperti berikut ini:

$Y^{\prime}=109,651+1,945 X_{1}+0,623 X_{2}$

Konstanta pada model persamaan tersebut sebesar 18,450. Dengan demikian, jika variabel status pegawai $\left(\mathrm{X}_{1}\right)$ dan job embeddedness $\left(\mathrm{X}_{2}\right)$ bernilai 0 , maka turnover intention (Y) bernilai 109,651. Koefisien regresi variabel organisasi pembelajaran $\left(\mathrm{X}_{1}\right)$ sebesar 1,945 Artinya, jika variabel status pegawai $\left(\mathrm{X}_{1}\right)$ ditingkatkan satu satuan dan nilai variabel job embeddedness $\left(\mathrm{X}_{2}\right)$ tetap, maka variabel turnover intention (Y) akan mengalami peningkatan sebesar 1,945 dan variabel status pegawai berpengaruh positif terhadap turnover intention .

\section{Hasil Analisis Koefisien Determinasi $\left(R^{2}\right)$}

Analisis determinasi dilakukan untuk mengetahui seberapa besar kontribusi pengaruh variabel bebas terhadap variabel terikat. Berikut adalah hasil analisis determinasi antara variabel organisasi pembelajaran, resiliensi karyawan dan keterikatan kerja.

Tabel 4.17

Hasil Uji Analisis Koefisien Determinasi $\left(\boldsymbol{R}^{2}\right)$

Model Summary

\begin{tabular}{rr|r|r|r}
\hline Model & R & R Square & Adjusted R Square & $\begin{array}{c}\text { Std. Error of the } \\
\text { Estimate }\end{array}$ \\
\hline 1 &, $731^{\mathrm{a}}$ &, 534 &, 528 & 9,225 \\
\hline
\end{tabular}


Jurnal Riset Manajemen Sains Indonesia (JRMSI) | Vol 12, No. 2, 2021 e-ISSN: 2301-8313

a. Predictors: (Constant), Job Embeddedness, Status Pegawai

\begin{abstract}
Berdasarkan Tabel 4.17, di atas diperoleh angka $\mathrm{R}^{2}$ (R Square) sebesar 0,534 atau (5,34\%). Hal ini menunjukkan bahwa tidak ada pengaruh yang kuat yang dipengaruhi oleh variabel status pegawai dan job embeddedness terhadap turnover intention, hanya 5,34\%. Sedangkan sisanya sebesar 94,66 \% dijelaskan atau dipengaruhi variabel lain yang tidak diteliti.
\end{abstract}

\title{
KESIMPULAN DAN SARAN
}

1). Karyawan honorer atau kontrak dilingkungan Universitas Negeri Jakarta tidak mempermasalahkan status kepegawaian karena merasa nyaman dengan lingkungan kerja ditunjang sulitnya lapangan kerja dan job embeddedness atau keterikatan terhapat pekerjaaan baik hal disebabkan karyawan merasa nilai-nilai yang dikembangkan pada organisasi sesuai dengan nilai individu. 2). Ada pengaruh secara signifikan antara status pegawai terhadap turnover intention demikian juga ada pengaruh secara sigifikan antara job embeddedness terhadap turnover intention.

\section{DAFTAR PUSTAKA}

Abdillah, Fuad. (2012), Hubungan Kohevisitas Kelompok Dengan Intensi Turnover Pada Karyawan. Journal of Social and Industrial Psychology, 1(2), 52-58.

Aditya, Bayu, Nugroho, \& Hakam, Moehammad, Soeoed. (2017), Pengaruh Status Pekerja dan Lingkungan Kerja Terhadap Kinerja Karyawan (Studi Pada Karyawan Auto 2000 Sukun Malang), Jurnal Administrasi Bisnis (JAB) Vol. 44. No 1.

Agung, W. N. C Handayani., dan W. Paramita. (2013). Pengaruh Kepuasan Kerja dan Stres Kerja Terhadap Turnover Intention Karyawan PT Unitex Bogor, Jurnal Riset Manajemen Sains Indonesia (JRMSI), 4(1), 97-115.

Armstrong, Michel. (2006). A Handbook of Human Resource Management Practice. Edisi kesepuluh. London : Cambridge University Press.

Aydogdo, Sinem., Baris Asikgil. 2011. An Empirical Study of The Relationship Among Job Satisfiction, Organizational Commiyment and Turnover Intention. International Review of Management and Marketing Vol. 1, No. 3, 2011, pp 43 - 53

Azeez, R. O. F. I. Jayeoba., A., O. Adeoye. (2016). Job Satisfaction, Turnover Intention and Organizational Commitment. Journal of Management Research, 82, 102-114. 
Jurnal Riset Manajemen Sains Indonesia (JRMSI) | Vol 12, No. 2, 2021 e-ISSN: 2301-8313

Burgess, John, Julia, Conell., 2006. Temporary work and Human Resources Management Issues, Challenges and Responses. Personal Review; 35 (2), pp : 129Burke, R. J. \& Greenglass, E. R. (2000). Work Status Congruence, Work Outcomes, and Psycological Wellbeing. Stress Med. 16 : 91-99-301

Burke, R. J. \& Greenglass, E. R. (2000). Work Status Congruence, Work Outcomes, and Psycological Weel-being. Strss Med. 16 : 91-99

Chambel, M. J. \& Castanheira, F. (2006). Different Tempory Work Status, Different Behaviors in Organization. Journal of Business and Psycology. Vol. 20, No.3

Conway, N. \& Briner, R. B. (2002) Full Time Versus Part Time Employess : Understanding The Link Between Work Status, The Psycological Contract, and Attitudes. Journal of Vocational Behavior. Vol 61, 279.

Crossley, Craig D. Bennett, Rebecca J. Jex, Steve M. Bernfield, Jennefer L. 2007. Development of Global Measure of Job Embeddedness and Integration Into a Traditional Model of Voluntary Turnover,. Journal of Applied Psychology, Vol 92 (4), 1031-1042.

Dijah Julindrastuti dan Imam Karyadi. (2016). Peran Status Kepegawaian Dalam Memoderasi Pengaruh Kepuasan Kerja Terhadap Komitmen Organisasional Karyawan, Dinamika Global, FEB UNEJ

Ida Ayu Putri Rarasanti \& I Suana Wayan. 2016. Pengaruh Job Embededness, Kepuasan Kerja dan Komitmen Organisasional Terhadap Turnover Intention, E-jurnal Manajemen Unud, Vol. 5, No 7 4690-4718.

Felps, Will., Terence R. Mitchell, David R. Hekman, Thomas W. Lee, Brooks c. Holtom, Wendy S. Harman. 2009. Turnover Contigion : How Cowokers Job Embeddedness and Job Search Behaviour Influence Quiting, Academy og Management Journal, 52 (3) , p : 547.

Fitriyani, Windri, 2013. Pengaruh Kepribadian dan Job Embeddedness Terhadap Organizational Citizenship Behavior (OCB) Pada Karyawan PT Hadji Kalla Makasar, Skripsi Fakultas Ekonomi \& Bisnis Universitas Hassanudin. P : 17.

Garnita, Ni Made Ayu., I Wayan Suana. (2014). Pengaruh Job Embeddedness dan Kepuasan Kerja Terhadap Turnover. E-Jurnal Manajemen Universitas Udayana. Vol.3, No 9.

Ghozali, Imam. 2016. Aplikasi Analisis Multivariate Dengan Program IBM SPSS 23 (edisi 8). Cetakan ke VIII. Semarang : Badan Penerbit Universitas Diponegoro.

Griffin, Ricky W. Dan Gregory Moorhead. (2014). Organizational Behavior : Managing People and Organizations. Elevent Edition, United of America : South-Western.

Handoko, T. Hani. (2014). Manajemen Personalia dan Sumber Daya Manusia. Edisi Kedua. Yogyakarta : BPFE 
Jurnal Riset Manajemen Sains Indonesia (JRMSI) | Vol 12, No. 2, 2021 e-ISSN: 2301-8313

Holtom, B. C., T. R Mitchell, \& T. W. Lee (2006). Incresing Human and Social Capital by Applying jobEmbeddedness Theory. Organization Dynamics, 35, 4, 316-331.

Kismono, Gugup. 2011. The Reletionships Beween Job Embeddedness, Work Family Conflict, and The Impact of Gender on Turnover Intention : Evidence From The Indonesian Banking Industry. Thesis of Piloshopy : pp : 1-10

Kreitner, Robert dan Angelo Kinicki. (2014). Organizational Behavior, edisi 5, Boston : McGraw-Hill.

Kurniawan, Emmanuel. 2013. Tahukah Anada ? Hak-hak Karyawan Tetap dan Kontrak. Dunia Cerdas. Jakarta.

Mitchell, T. R, Holtom, B. C., Lee, T. W., Sablinsky, C. J., \& Erez, M. (2001). Why People Stay : Using Job Embeddedness to Predict Voluntary aturnover, Academy of Management Journal, 44, 1102-1122.

Putri, C. L,. (2012). Pengaruh Kepuasan Kerja dan Dimensi-dimensi On The Job Embeddedness Terhadap Intensi Untuk Meninggalkan Pekerjaan Pada Karyawan PT X. Depok : Universitas Indonesia.

Robbins SP, dan Thimothy A judge, 2015. Perilaku Organisasi. Jakarta : Salemba Empat

Sari, D. (2012). Hubungan Status Kerja, Job Inscurity, dam Kepuasan Kerja : Keadilan Organisasi Sebagai Moderasi ( Studi Pada Perbedaan Status Kerja di Universitas Indonesia). Depok : Universitas Indonesia.

Stamper, C. L. \& Van Dyne, L. (2001). Work Status and Organizational Citizenship Behavior : a Frend Study of Restaurant employees. Journal of Organizational Behavior. 22, 517-536

Wijayanto, R. B. \& Kismono, G. (2004). The effect of Job Embeddedness on Organizational Citizenship Behavior : The Mediating Role of Sense of Responbility. Gajah Mada International Journal of Business. Vol. 6, No. 3, 335-354

Zhang, M., Fried, D. D., \& Griffeth, R. W. (2012). Human Resource Management Review A Review of Job Embeddedness : Conceptual, Measurement Issues, and Directions for Future Research. Human Resource Management Review, 22(3), 220-231. http://doi.org/10.1016/j.hrmr.2012.02.004 